\title{
AN ASSESSMENT OF GASTRIC ACID SECRETORY RESPONSE WITH 'MAXIMAL' AUGMENTED HISTAMINE STIMULATION IN CHILDREN WITH PEPTIC ULCER
}

\author{
BY \\ O. P. GHAI, MEHARBAN SINGH, B. N. S. WALIA, and N. G. GADEKAR \\ From the Departments of Pediatrics and Radiology, All India Institute of Medical Sciences, New Delhi, India
}

(RECEIVED FOR PUBLICATION JUNE 1, 1964)

Numerous recent reports have outlined the clinical profile of childhood peptic ulcer (Alexander, 1951; Fallstrom and Reinand, 1961; Gadiyar, Taneja, and Ghai, 1963; Girdany, 1953; Michener, Kennedy, and Du Shane, 1960; Muggia and Spiro, 1959; Ramirez Ramos, Kirsner, and Palmer, 1960). Investigation of its pathogenesis, however, has not received much attention. There is general agreement that peptic ulceration cannot persist in the absence of acid and pepsin (Grossman, 1951). The concept of a physiological balance between two sets of opposing forces, i.e. the hydrochloric acid and pepsin on the one hand and mucosal resistance on the other, have given a dynamic approach to the problem (Shay, 1959). The present study was undertaken to assess the role of gastric hydrochloric acid in the aetio-pathogenesis of childhood duodenal ulcer.

\section{Material and Method}

Sixteen children with minor illnesses unrelated to the gastro-intestinal tract and 18 radiologically proved cases of duodenal ulcer with a crater were studied for gastric acid secretory capacity with the 'maximal' augmented histamine test (Kay, 1953, modified by Card and Marks, 1960). A triple sedative (pethidine $1.5 \mathrm{mg} . / \mathrm{kg}$., chlorpromazine $0.5 \mathrm{mg}$. $/ \mathrm{kg}$., and promethazine 0.5 $\mathrm{mg}$./kg.) was injected subcutaneously half an hour before intubation. The position of the tube was checked by fluoroscopy. Suction pressure was kept between 10-15 $\mathrm{cm}$. of water. The results of total acidity were expressed as (i) basal acid output (BAO) or the first hour interdigestive secretion; (ii) the 'maximal' acid output (MAO) or the post histamine one-hour secretion.

\section{Results}

The results of the investigation are summarized in Tables 1 and 2, and Fig. 1.

The test was repeated in two patients with duodenal ulcer after four to six months of relief from symptoms. Radiologically healing had taken place. There was no significant change in basal acid output, but MAO was reduced from the initial values of $15 \cdot 71$ and $11 \cdot 82$ to $7 \cdot 31(53 \%$ drop) and $4 \cdot 82(61 \%$ drop).

\section{Discussion}

There are few published reports of gastric secretory pattern after a test meal or histamine stimulation in childhood peptic ulcer. It appears that the 'maximal' augmented histamine test has not so far been employed in children.

The mean basal and maximal acid outputs in our control subjects were $0.32 \mathrm{mEq} . / 10 \mathrm{~kg}$. hour and $2.02 \mathrm{mEq} / 10 \mathrm{~kg}$. hour, respectively. A significant correlation between maximal acid output and the weight of the child was obtained (Fig. 1). This conforms to the belief that increase in the size of the

TABLE 1

COMPARATIVE DATA ON AGE, WEIGHT, HEIGHT, AND GASTRIC ACID SECRETION IN TWO GROUPS

\begin{tabular}{|c|c|c|c|}
\hline & & Patients & Controls \\
\hline $\begin{array}{l}\text { No. of cases } \\
\text { Mean age (yr.) } \\
\text { Mean weight (kg.) } \\
\text { Mean height (cm.) } \\
\text { BAO (mEq/hour) } \\
\text { MAO (mEq/hour) }\end{array}$ & \begin{tabular}{l|}
$\cdots$ \\
$\cdots$ \\
$\cdots$ \\
$\cdots$ \\
$\cdots$
\end{tabular} & $\begin{array}{c}18 \\
11 \cdot 3 \\
28 \cdot 2 \\
134 \\
1 \cdot 04 \pm 0 \cdot 05 \\
(0 \cdot 38-2 \cdot 10) \\
8 \cdot 39 \pm 0 \cdot 72 \\
(4 \cdot 15-15 \cdot 70)\end{array}$ & $\begin{array}{c}16 \\
10 \cdot 9 \\
25 \cdot 3 \\
130 \\
0 \cdot 83 \pm 0 \cdot 05 \\
(0 \cdot 24-2 \cdot 09) \\
5 \cdot 25 \pm 0 \cdot 48 \\
(2 \cdot 82-9 \cdot 85)\end{array}$ \\
\hline
\end{tabular}

TABLE 2

GASTRIC ACID SECRETORY PATTERN IN ACTIVE AND QUIESCENT ULCER CASES

\begin{tabular}{|c|c|c|c|}
\hline & & Active Ulcer & Quiescent Ulcer \\
\hline $\begin{array}{l}\text { No. of cases } \\
\text { BAO (mEq/hour) } \\
\text { MAO (mEq/hour) }\end{array}$ & $\begin{array}{l}\cdots \\
\cdots \\
\cdots\end{array}$ & $\begin{array}{c}10 \\
1 \cdot 16 \pm 0 \cdot 02 \\
(0 \cdot 38-2 \cdot 10) \\
10 \cdot 10 \pm 0 \cdot 88 \\
(7 \cdot 05-15 \cdot 70)\end{array}$ & $\begin{array}{c}8 \\
0 \cdot 89 \pm 0 \cdot 01 \\
(0 \cdot 52 \pm 1 \cdot 50) \\
6 \cdot 25 \pm 0 \cdot 62 \\
(4 \cdot 15 \cdot-9 \cdot 40)\end{array}$ \\
\hline
\end{tabular}

$\mathrm{p}<0.001$ for control and active ulcers (MAO only). $\mathrm{p}<0.01$ for active and quiescent ulcers (MAO only). $\mathrm{p}$ insignificant for control and quiescent ulcers (MAO only) 


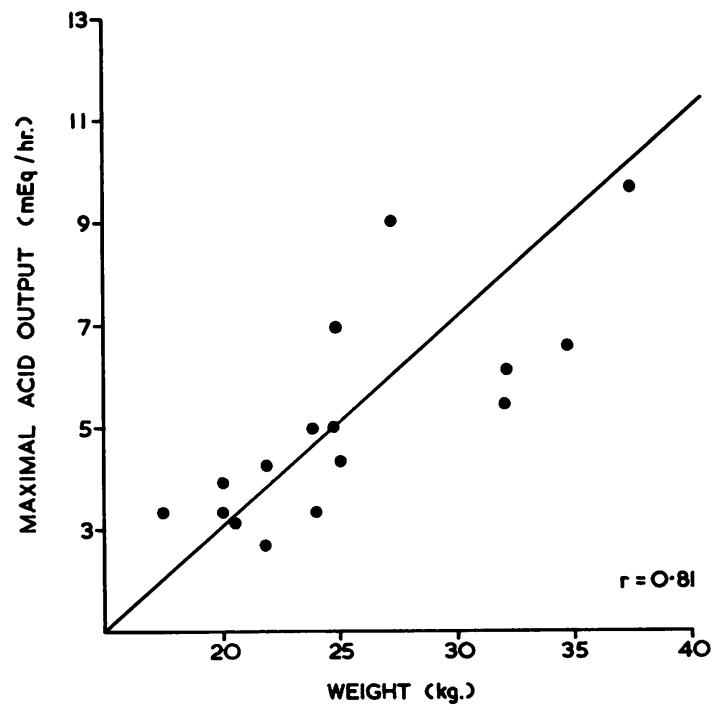

FIG. 1.-Relation between maximal acid output and body weight.

child is associated with growth of the stomach and hence an increase in the parietal cell mass (W. I. Card, 1963, personal communication).

The mean basal acid output in duodenal ulcer patients was $0.43 \mathrm{mEq} / 10 \mathrm{~kg}$. hour. There was no significant difference in the basal acid ouput of the two groups. This is in contrast to the findings in the adults where mean basal acid output in duodenal ulcer patients is significantly higher than in the controls. The exact significance of these findings is unknown. It may be due partly to suppression of basal secretory mechanisms by large doses of pethidine, chlorpromazine, and promethazine, which were given to all these children.

Of the duodenal ulcer patients, $11(61 \%)$ secreted maximal acid of more than $2.50 \mathrm{mEq} / 10 \mathrm{~kg}$. hr., while only 3 controls $(19 \%)$ secreted that amount. A correlation between high maximal acid output and activity of the ulcer at the time of the first test was observed. Serial estimations of MAO in 2 patients showed a fall during the quiescent phase of the ulcer. No such relation was seen with basal secretion (Table 2). Bolo, Palol, and Los Santos (1961), while studying basal gastric secretions in 199 adults with duodenal ulcer, reported that during activity while $86 \%$ of them showed hyperchlorhydria, during quiescence, only $36 \%$ showed hyperacidity. Littman (1962) showed a clear drop in basal secretion in 9 patients with duodenal ulcer during their first remission.

Maximal acid output obtained under the conditions of the original test is considered as a fairly good index of parietal cell mass (Card and Marks, 1960; Cox, 1952; Marks, 1956; Tongen, 1950). However, it does not represent the maximal secretory capacity of the stomach under all conditions. Ward, Gillespie, Passaro, and Grossman (1963), have shown that by the use of histalog in doses of $100 \mathrm{mg}$. subcutaneously, the gastric acid output is much higher than that obtained with the 'maximal' augmented histamine test. It is difficult to explain the exact significance of the positive correlation between MAO and the activity of the ulcer. It is possible that in the active phase the parietal cells are in a hyperexcitable state, so that heightened secretory response to exogenous stimulus is obtained. This 'end-organ excitatory tonus' may also exist for stimuli other than histamine, resulting in perpetuation of ulceration. However, more observations are needed to confirm these findings.

\section{Summary}

The results of the 'maximal' augmented histamine test on 18 radiologically proven cases of duodenal ulcer in children and 16 control subjects are presented. All received triple sedative injection half an hour before the start of the test. The mean basal and the maximal acid output in control subjects were 0.32 $\mathrm{mEq} / 10 \mathrm{~kg}$. hour and $2.02 \mathrm{mEq} / 10 \mathrm{~kg}$. hour, respectively. There was a significant correlation between body weight and 'maximal' acid output in control subjects. There was no significant difference between basal outputs in duodenal ulcer patients and control subjects. Eleven patients with duodenal ulcer $(61 \%)$ secreted 'maximal' acid in amounts more than $2.50 \mathrm{mEq} / 10 \mathrm{~kg}$. hour while only 3 control children $(19 \%)$ did so. A direct correlation between the activity of the ulcer and maximal acid output was observed. The significance of these findings is discussed.

\section{REFERENCES}

Alexander, F. K. (1951). Duodenal ulcer in children, Radiology, 56, 799.

Bolo, P. O., Palol, J. de, and Los Santos, M. A. de (1961). Correlation of basal gastric secretion with peptic ulcer activity. Amer. J. dig. Dis., 6, 784.

Card, W. I., and Marks, I. N. (1960). The relationship between the acid output of the stomach following 'maximal' histamine stimulation and the parietal cell mass. Clin. Sci., 19, 147.

Cox, A. J., Jr. (1952). Stomach size and its relation to chronic peptic ulcer, Arch. Path., 54, 407.

Fallstrom, S. P., and Reinand, T. (1961). Peptic ulcer in children. Acta paediat. (Uppsala) 50, 431 .

Gadiyar, B. N., Taneja, P. N., and Ghai, O. P. (1963). Recurrent pain in abdomen in children. Indian J. Child Hlth, 12, 289.

Girdany, B. R. (1953). Peptic ulcer in childhood. Pediatrics, 12, 56.

Grossman, M. I. (1951). A critical analysis of various theories of the pathogenesis of peptic ulcer. In Peptic Ulcer, ed. D. J. Sandweiss. Saunders, Philadelphia.

Kay, A. W. (1953). Effect of large doses of histamine on gastric secretion of $\mathrm{HCl}$ : an augmented histamine test. Brit. med.J., 2 , 77. 
Littman, A. (1962). Basal gastric secretion in patients with duodenal ulcer: a long term study of variations in relation to ulcer activity. Gastroenterology, 43, 166.

Marks, I. N. (1956). The relationship of the acid output of the parietal cell population of the stomach. Scot. med. J., 1, 242.

Michener, W. M., Kennedy, R. L. J., and Du Shane, J. W. (1960) Duodenal ulcer in childhood. Amer. J. Dis. Child., 100, 814.

Muggia, A., and Spiro, H. M. (1959). Childhood peptic ulcer. Gastroenterology, 37, 715 .
Ramirez Ramos, A., Kirsner, J. B., and Palmer, W. L. (1960). Peptic ulcer in children. Amer. J. Dis. Child., 99, 135.

Shay, H. (1959). Emotional stress and parietal cell mass: their role in the aetiology of peptic ulcer. Amer. J. dig. Dis., 4, 846.

Tongen, L. A. (1950). The quantitative relationship between parietal cells and gastric acidity. Surgery, 28, 1009.

Ward, S., Gillespie, I. E., Passaro, E. P., and Grossman, M. I. (1963) Comparison of histalog and histamine as stimulants for maximal gastric secretion in human subjects and in dogs. Gastroenterology, 44, 620 . 